$\xi=-1$

\title{
Human capital accumulation of rural female migrants and occupational mobility at destination area: A case study of Chonburi
}

\author{
Soiboon Saithong ${ }^{1}$, Dusadee Ayuwat ${ }^{1 *}$, Oranutda Chinnasri $^{2}$ \\ ${ }^{1}$ Department of Sociology and Anthropology, Labour and International Migration Service Center, \\ Faculty of Humanities and Social Sciences, Khon Kean University, Thailand.. \\ ${ }^{2}$ Department of Sociology and Anthropology, Faculty of Social Sciences, Kasetsart University, Thailand \\ *Corresponding author E-mail:dusayu@kku.ac.th
}

\begin{abstract}
Occupational mobility influences the social status of female migrants who have migrated from rural to urban areas. Occupational progression leads to social class mobility. The purpose of this research was to examine human capital accumulation and occupational mobility among female migrants in the destination area. Using qualitative methodology, in-depth interviews were conducted with 26 female migrants from the rural Northeast of Thailand to Chonburi Province and with 6 key informants between October 2015 to January 2016. The data were analyzed by analytic description. The findings indicated that the female migrants from the rural Northeast of Thailand relied on multiple ways of accumulating human capital for occupational mobility, namely: 1) learning on the job, resulting in an advancement from working as a cook's assistant, waitress, or assembly line worker (Level 1 skills) to working as a tourist guide, noodle vendor, or beauty parlor/general store operator (Level 2 skills);2) attending adult education, which led to occupational advancement from being a domestic worker (Level 1 skills) to an accountant in a private company (Level 2 skills);3) studying at a formal educational institution, which helped a domestic worker to assume a position as a clerk at a state agency (Level 2 skills);4) vocational short course training, which led in occupational advancement from being an assembly line worker to opening a sewing shop (Level 2 skills). In conclusion, the findings indicated that these female migrant's way of human capital accumulation influenced their occupational mobility, but it also depended on their personal characteristics.
\end{abstract}

Keywords: Human Capital Accumulation, Form of Occupational Mobility, Female Migrants at Destination

\section{Introduction}

The migration of Thai women within the country is a distinct phenomenon that has occurred after the $1^{\text {st }}$ National Social and Economic Development Plan (1961-1966) came into use, as can be seen from the census of the population of Thailand in 1960 that showed as high as 47,067 female migrants who moved to Bangkok [1]. The trend of migration from the Northeast to the destination in Bangkok and the greater Bangkok has excessively increased until the problem of population congestion prevails [2]. When the $5^{\text {th }}-7^{\text {th }}$ National Social and Economic Development Plans (1982-1996) came into use and aimed to expand industrial areas, Chonburi Province has rapidly been developed in many aspects, resulting in an increase in the level of industrial development. The province became the biggest center for marine import and export of goods in the Southeast Asia and a tourist hub that led to the level of a metropolitan city. Chonburi has become the place of migration attraction, especially among female laborers from the Northeast. It was found that in 2013, the number of migrants from rural Northeast to Chonburi was the highest. The number of male and female migrants did not differ much $[3,4,5$, 6], with females accounting for $46.9 \%$ of labor [7]. Considering the main cause for the migration, it was found that the motivation for the movement is to earn for a living and expectation for higher income, resulting in higher social and economic status.

However, it is found that the educational level of the majority of females who migrate from rural areas of the Northeast is below the bachelor's degree level. Therefore, when looking for jobs in the city, these female migrants are obliged to accumulate their own capital in order to be able to hold better jobs, increase their income and raise their social level. It can be understood that the pride, the power and being recognized in their own profession would bring them higher prestige [8]. The purpose for migration of females from rural areas of the Northeast is to find an area for human capital accumulation. This is due to the fact that cities offer higher possibilities for capital gains, making possible acquisition of wealth in different forms [9]. Apart from this, a research study has discovered that the level of industrial development and the status of a city influence occupational mobility, which is greatly probable in the areas of major cities [10]. Therefore, the researchers believe that human capital accumulation of female migrants from the rural Northeast could possibly affect occupational mobility, which correlates to occupational success and social mobility, too.

\section{Research objective}

This research aimed to study the effect of human capital accumulation of female migrants from the rural Northeast on occupational mobility at their destination, Chonburi Province, Thailand. 


\section{Theory and conceptual framework}

The researchers applied Becker's [11] human capital accumulation concept, which is based on the fact that an individual's choice of education and training as well as the way to increase knowledge arise from comparison between benefits and costs. The benefits include culture and items other than monetary derived from earnings and occupations. Investment costs are considered in the framework of the investment period. In addition, the researchers applied the indicators for human capital developed by Lisbon Council and Deutschland Denken [12]. The indicators related to human capital assurances that support economic activities were chosen, namely: 1) learning on the job, 2) adult education, 3) university education, 4) primary and secondary schooling, and 5) parental education; all of which are individual level of human capital accumulation. Therefore, human capital accumulation of female migrants means the methods used by the women to accumulate their own human capital, which are education and training for income-raising occupations. There are 4 human capital accumulation methods of migrating women, namely: 1) learning on the job 2) learning from adult education 3) learning in an education institute and 4) short course training for occupation skill.

The researchers have applied the theory of intrageneration occupational mobility for the major groups of female migrants by noting their mobility in the form of vertical occupational mobility [13, 14] which is the cross-occupational mobility from level-1 skill to level-2 skill, based on the International Standard Classification of Occupations (ISCO-08) stipulated by the International Labour Office 2012 (ILO) $[15,16]$. Thus, the mobility structure may be in 3 forms, i.e., upward occupational mobility, downward occupational mobility and non-occupational mobility.

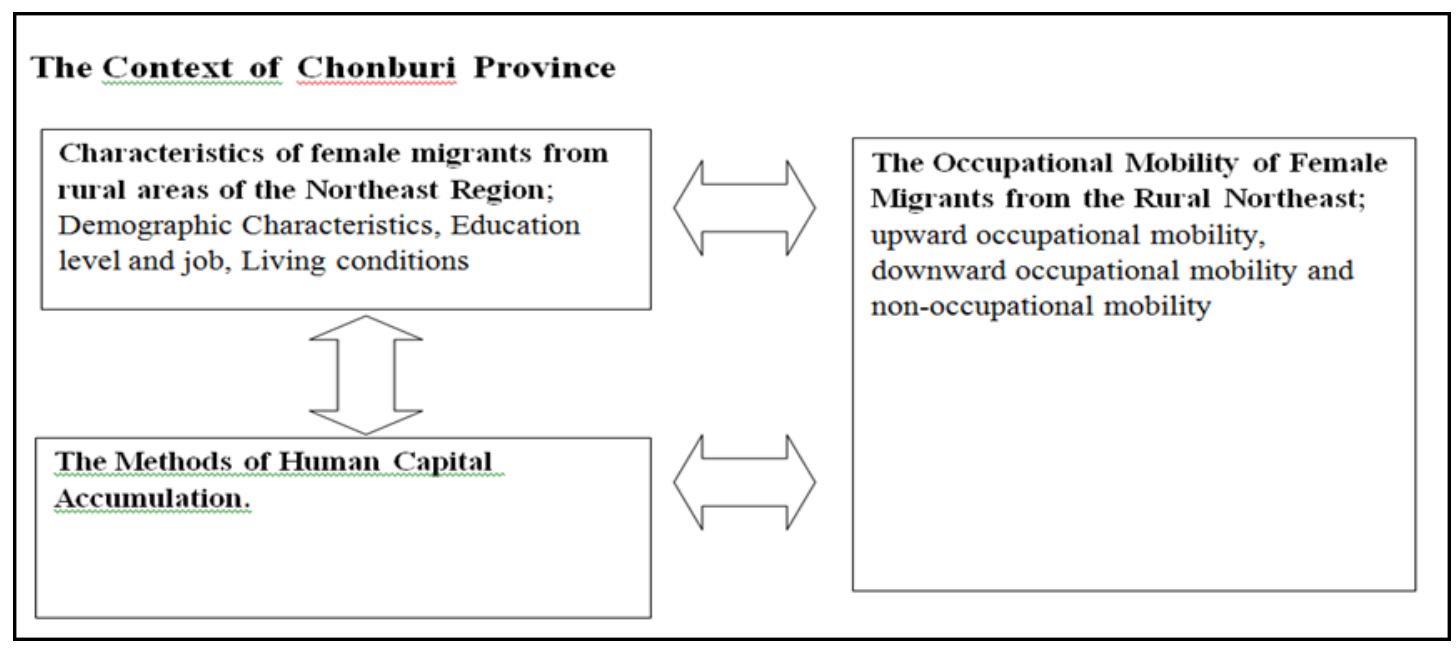

Fig. 1. Conceptual Framework

\section{Methodology}

This research used the qualitative method which gives importance to social phenomena arising from interpretative assumption and the case study method $[17,18]$ in order to obtain in-depth data, understanding of human capital accumulation of female migrants by means of areal context understanding. The unit of analysis was an individual level. In-depth interviews were conducted with 26 female migrants from the rural Northeast, purposively selected based on the following inclusive criteria: (1) women who migrated from the rural Northeast, ages between 20-45 years old, (2) workers with income, (3) residents within the urban area of Chonburi for a period between 1-10 years, (4) women working in the 5 primary occupation groups: the $4^{\text {th }}$ occupation group: clerk, the $5^{\text {th }}$ occupation group: service employee, employee of shop/market, the $7^{\text {th }}$ occupation group: skilled worker and worker in relating trade, the $8^{\text {th }}$ occupation group: factory/machinery operator and assembly worker, the $9^{\text {th }}$ occupation group: fundamental level of jobs in sales and service. All of these primary occupations were found being mostly held by female migrants in Chonburi Province $[5,6]$. The snowball technique was applied in the search for the sample group. The interviews were performed both at their working place and residence, enabling the researchers to also observe their way of life. Mainly Isan language was used in these interviews for appropriate access to the data.

Additionally, in-depth interviews were performed with 6 key informants, or those who are connected with the potentiality development of female migrants, based on purposive selection criteria: (1) those directly responsible for capacity building in knowledge, occupational skills, and life skill for female migrants who are working in their place of destination, and (2) those working in a government or private sector or a community organization such as government officials responsible for professional training, private enterprises, non-profit enterprises, officials from Isan migration associations and private enterprises. The people and organizations as mentioned above are in Chonburi Province with potential to provide information on the context, situations, occupational training, capability development, and ways of living of female migrants from the Northeast to Chonburi. Data collection was conducted from October 2015 to January 2016 and January 2017. The content analysis was performed for drawing conclusion of the study.

\section{Results}

\subsection{Chonburi province}

Chonburi is a province in the East of Thailand, 65 kilometers from Bangkok with the coast of 156.83 kilometers long. It was one of the major cities under the $5^{\text {th }}$ National Economic and Social Development Plan (1982-1986). The developmental implementation was done under the Eastern Seaboard Development Program (ESB). This resulted in the establishment of public facilities and infrastructures in the city to support the economic growth, such as land transport which connects to all regions of the country and a deep sea port at Laem Chabang as a center for sea transportation. In addition, due to the Government's policy to encourage various foreign industrial investments, many large industrial settlements have been established with continued support to property investors enabling Chonburi Province to grow rapidly and become an established city as can be seen in the districts of Pattaya, Banglamoong, Sriracha and Muang Chonburi, with various job opportunities for women in production industries, tourism and services.

\subsection{Characteristics of female migrants from rural are-} as of the northeast region 
In this sector, the main target for the researchers is presentation of the characteristics of female migrants target group regarding occupations, incomes, their accommodation, age, education, marital status, length of stay in Chonburi Province, previous occupations before moving to Chonburi Province, present occupations, present income, with details as follows:

\subsubsection{Demographic Characteristics}

The result of the research showed that among the target group of working female migrants, the lowest age was 20 years and oldest was 44 years old. They moved to and worked in the vicinity of Chonburi Province in varying periods from 1 to 10 years. The length of stay in their destination affected their occupational mobility [10]. It was noted that jobs were available for various age ranges in Chonburi Province.

In terms of marital status, it was found that there were 7 single women, 10 were married to Thai nationals and lived together with their spouses at their destination city. Among these, there was only one couple who had children. Four women were married to and already separated from foreign spouses and did not have children. Five were divorced and became single mothers, two of whom had their children living with them who were sent to nearby schools. This shows that apart from earning a living, these migrant females also had to bring up their children and did their responsibility as a wife at the same time.

\subsubsection{Education level and job}

The educational level of the female migrants prior to moving to Chonburi Province was as follows: 6 held a bachelor degree and the rest completed their education below this level, which affected their employment. It was found that their former job which was also their first job in Chonburi was being a blue collar worker who received daily wage. The majority did not receive any fringe benefits. This included skill levels 1 and 2, for example, being general employees in massage parlors (due to not having any massage skills, they had to do general work in the parlor), manufacturing staff in industrial factories who packed products manually (this is a job easily found as there are a large number of labor contractors providing labor services in various industrial estates), shop assistants in convenient stores, masseurs, hair dressers, employees in entertainment places, house maids, cook assistants, waitresses, construction workers (carrying cement buckets), or golf caddies. However, it was found that 6 female migrants who held a bachelor's degree were able to work as white-collar workers in both government agencies and private enterprises with monthly salary including fringe benefits. This was considered the level- 2 skill occupation.

Educational level and current occupation - The research showed that there were 19 female migrants whose education was below bachelor's degree level and 7 with bachelor's degree (an increase of 1). Female migrants who were university graduates work in the major group 4: clerical support workers, which is considered level 2 , clerk in government agencies, clerk in personnel section of private enterprises, secretary, inspector of raw materials. The type of work reflected that those holding a bachelor's degree were able to perform quality work (white collar workers) with monthly salary of 15,000-30,000 Baht per month (US 442-884). Apart from this, they also received fringe benefits in accordance with the law. Their jobs were therefore secure and they were in a good environment with average professional dignity [8]. The major group 4: clerical support workers, is held by females more than males according to the whole country's survey [19].

At the same time, it was found that female migrants who completed their education lower than a bachelor's degree level worked in the major groups 5: services and sales workers, considered as level-2 skill occupations. Some were owners of Isan food stalls, noodle shops, grocery shops, beauty salons. All of the women who had these jobs used to be employed in a business. However, they had ambition of becoming business owners themselves so that they had more freedom in their work. They also wanted to be their own boss and able to handle their own money. The income of these business owners were between 18,000-45,000 Baht per month (US\$529-1,324) which is considered an honorable profession of a medium level [8].

Additionally, it was also found that female migrants worked under the major group 8: plant and machine operators and assemblers, considered level-2 skill occupations. These included owner of dress making shop (designing, making patterns, cutting and sewing). The female migrants holding this occupation completed primary educational level with prior experience in clothing industry and construction work. These women sought for a chance to learn dress making from dress making schools enabling them to take up this profession which is considered a respectable job of medium level. ${ }^{8}$ Even though the monthly income was not steady, there was freedom, as one female migrant said "...My income each month is less than when working at the factory, but I think it is better because I have more freedom and more time to relax....."

Female migrants with lower education level than bachelor's degree were at present working under the major group 9: elementary occupations with level-1 skill because the job requires simple skills that can be done by hand. Some women were employed as production staff in industrial factories, Thai masseurs, workers in entertainment places, workers in convenient stores, workers in hair salons, waitresses in noodle shops, maids, tourist guides (to guide company's clients to stipulated places). These are jobs considered to be of a more physical nature, i.e., blue collar workers. They earned daily wages for each day they worked and were paid every 15 days. The income of this group was between 9,000-17,000 Baht per month with benefits only as stipulated by law but without any job security. At the same time, the study by Chantavanich [8] discovered that this is considered a job of low level - especially workers in entertainment places.

\subsubsection{Living conditions}

The research revealed that female migrants rented their accommodation that was suitable, convenient when considering the work place, and inexpensive compared to their income. For example, female migrants who worked in industrial estates rented a dormitory or an apartment with facilities in front of the entrance of the industrial estate where there were many places opened for rent, making it clearly a large community. Female migrants who worked in Pattaya city which is a tourism and entertainment place rented a small room in a commercial building, for the place was convenient for them to go to work. Female migrants who owned a business such as a beauty salon rented a one-storey row building where they made it a salon as well as a house. The migrating women who made ready-made food for sale in the urban area rent a piece of land together with their relatives who worked in similar jobs in the suburban area of the city where they built a temporary living quarter for preparing food. The condition of their living quarters reflected their intention to live in their final destination only for a short period of time. They planned to return to their home town once they had reached their goal such as earning enough money to send their children to school until they finish their education and are employed. Some expected to earn an amount of money before returning home.

\subsection{Human capital accumulation}

The findings from the research on human capital accumulation of female migrants can be classified into 4 categories as follows:

\subsubsection{Learning from the Job}

This is a way to accumulate human capital which female migrants acquired from practice when they began their work or learned 
from the job. Female migrants had to learn various specific skills necessary for their own personal benefits that enabled them to carry out their responsibility required by the job. This kind of learning took place every time they started a new job or a new occupation. The research discovered that there were 3 types of practices that enabled females to accumulate their human capital: 1) real practices, 2) self-learning, and 3) learning from secondhand information, the details of which are as follows:

1) On the Job Training is a way to learn from real practices or in other words "on hand" which is one-on-one learning from a skillful worker who acts as a mentor and builds up one's confidence.

2) Self Learning means learning by oneself during job operation. This requires a will to acquire skills or knowledge from observation and memorization of things happening and apply it in the work, as an accountant of a private company stated:

“...When I first worked here, I had never done any kind of work connected to tourism before. Once I came here, I had to watch what they were doing, what was relevant. My responsibility was to remember all the company's boats and the boatmen. I had to remember what kind of motor each boat used, how much petrol it used each trip back and forth. Also I had to note down the amount of petrol used and note it down in the account. I had to be alert and observant. I have not learnt anything about accounting program before, but when I worked, I tried to observe how my colleagues did it, how they entered the program, the calculation system that they used. I trained myself and in the end, I could do it..." (Nam - a pseudonym, age 33 years, interviewed in November 2013)

3) Information Learning means a way to increase knowledge by oneself from various sources such as from books, internet or other on line services. Once information was obtained, the females started to try it out, as said by the owner of a beauty salon who finished primary school Grade 6:

"...We have to be fast with hair styles and be up to date. See how they do it and then try it out on a dummy, but you have to know how to be flexible. Like when a client wants a new hair style, we have to know which part to cover and which to make more prominent. Regular practices make us become skillful..." (Mali a pseudonym, age 44 years, interviewed in January, 2016).

It is apparent that human capital accumulation by information learning may occur in many ways. Female migrants adjusted themselves in order to acquire knowledge from their surroundings in order to further develop themselves and increase their capabilities in their own jobs in order to accumulate and upgrade their human capital. This enabled them to hold higherlevel of occupations and hence higher returns.

\subsubsection{Learning from the adult education}

This human capital accumulation is through attending the nonformal education for adults or a special course such as evening classes or classes during holidays, both of which are organized by both the state and private education institutes for vocational and higher vocational certificate levels. A female migrant who completed secondary school, voluntarily changed her job for less pay, choosing to work as maid in order to have time to study during $5.00-7.00$ p.m. and weekend courses near her working place in order to save transportation costs. This woman's efforts enabled her to complete her studies and found a better job with better pay and better standard of living. At present she is working as a clerk in the accounting section of a private company. She said:

"...At the old job, I noticed the people around me: the ones who got higher pay and good positions were highly educated. There was only myself who finished grade 12. I had worked in many places and felt that my life should be better than this. I decided that I must find a way to further my studies. Therefore, I chose to work as a house maid. It gave me time to study in the evenings or on weekends. I eat and sleep in the house where I worked and reduced my expenses. I also didn't have to dress much because my real goal is to further my studies. I told my employer that I was going to study, and the employer didn't object. I did not receive payment every month because I asked my employer to keep it for me. When the school term opened and I needed money, I then asked for it. I studied for two years and received my vocational certificate. I resigned and got a job in accounting with good pay..." (Supa - a pseudonym, age 34 years, interviewed in January 2016).

\subsubsection{Learning in an education institute}

Some female migrants continued their studies in the mainstream channel in order to obtain a bachelor's degree or higher. The majority of female migrants completed their education at a level lower than bachelor's degree when they first migrated, but had the intention to get a degree. Therefore, they chose to be employed where they could arrange for sufficient time to further their studies such as this particular female migrant who completed primary level. She was single when she moved (at present married), intended to improve herself by obtaining higher education so that she could change her job from being a maid. She decided to attend non-formal education which opened near her employer's house. She completed secondary school and high school before entering an open university. Female migrants used this method to continue their studies, learn from their job and train to use a computer and a foreign language as in the case told by a government official:

"...I used the insults of my employer as incentive to push me forward. While I was studying, sometimes my employer would complain about my work, but I tolerated it because I knew what my aim was and studied step by step. When I graduated and received 2 bachelor's degrees, I had to thank my employer who was behind my attempts until I am what I am today..." (Queen - a pseudonym, age 39 years, interviewed in January 2559).

\subsubsection{Short course training for occupation skills}

Female migrants increased their professional skills by attending short course training so that they had the skills appropriate to their work such as basics of computer for general use, dress making, caddy, traditional Thai massage, hair dressing. The training of such skills helped them to get into the profession immediately. However, there were expenses for training and 3-6 months of time spent. Apart from this, some female migrants received skill training in non-profit organizations for lower expenses. Here, they were able to organize their time for training between 09.00 a.m. 2.00 p.m., thus enabling them to work in the evening until late at night. Female migrants who gained professional skills in this way lived in the place of destination and had done low-skill jobs for a period of time. They wished to improve their own status in order to have a better profession. Female migrants therefore had to consider the possibility of holding a job with income worthy of time and expenses spent in training.

\subsection{Capital accumulation and occupational mobility}

ISCO-08 international standard was applied in the categorization of female migrants' occupation categories which follows the types of work, education and skill ranking. Therefore, the researchers considered cross occupational mobility. Advancement from skills level 1 to level 2 was considered changing to a higher level. On the contrary, if career crossing was from skills level 2 to level 1 , it was considered downward mobility. However, if the change was within the same occupational category, it was considered that nonmobility. Also, if the change was across the categories but within the same skill level, no mobility occurred. The consideration was based on the former occupation or the first job the female migrants did when the first arrived in Chonburi and the present occupation in this province (Table 1).

When this definition was used to analyze occupation mobility be 
comparing the first and present occupations at the destination, it was found that 7 female migrants advanced their occupations. Those moving from Level 1 to Level 2 were: employees in business places such as caddy, waitress in massage parlor, hand packaging factory worker, and construction worker. They moved to Level-2 jobs including being an entrepreneur such as owner of Isan food stall, owner of a noodle shop, owner of a grocery store, owner of a beauty salon or dress maker. It was found that one group moved from Level 1 such as an employee in a convenient store who checked and filled the shop shelves or a house maid across the category to Level 2, being a blue collar worker or white collar worker such as raw material controller for factories, state employee and accountant in a private enterprise (Table 1).

However, the research found that there were 2 female migrants who stepped down in level by moving from Level-2 jobs as a cashier in a hotel restaurant and hotel greeting staff to work in Level-1 occupation, i.e., a grocery store/checking and refilling goods on shop shelves and waitress at a noodle shop (Table 1). Additionally, it was found that 17 female migrants did not change their career across the categories, but moved to other jobs at the same skill level. Ten were working as employees under level 1 and level 2: being a masseuse, a hair dresser, a worker in an enter- tainment place, a worker in manufacturing industries doing hand packaging jobs, a shop assistant in a convenient store. These females remained at the same job level because their education level was lower than a bachelor's degree.

As for female migrants who were at level 2 since their arrival in Chonburi, 7 were found working as a clerk in government organizations, a secretary, a clerk in personnel section, an accountant in a private company, and clerical staff in sale and marketing of a condominium. They still worked in this level because of good income, good benefits and stability (Table 1).

The analysis of capital accumulation and occupational mobility showed that human capital accumulation by seeking higher education in non-formal education and educational institution enabled female migrants to move up in their career from Level 1 to Level 2 , becoming clerks in both state enterprises and private sectors since the level of education is a vital factor. However, learning from place of work by actual practice, or self learning from secondary information also helped them to raise their career level from 1 to 2 , by becoming self employed such as in a trade and service business. As for groups that stepped down or did not move up, it was found that they learned from the work place or took short training courses (Table 2).

Table 1: To Show Number of Occupational Mobility of Female Migrants at Chonburi Province

\begin{tabular}{|c|c|c|c|c|}
\hline \multirow[b]{2}{*}{ First Occupation (number) } & \multicolumn{4}{|l|}{ Current Occupation (number) } \\
\hline & Blue Collar Worker (12) & Entrepreneur (5) & $\begin{array}{l}\begin{array}{l}\text { White } \\
(\text { Clerk)(9) }\end{array} \\
\text { Collar } \quad \text { Worker } \\
\end{array}$ & Total \\
\hline Blue Collar Worker(18) & $\begin{array}{l}\text { non-occupational mobility }=\mathbf{1 0} ; \\
\text { downward occupational mobility = } \\
1\end{array}$ & $\begin{array}{l}\text { upward occupational } \\
\text { mobility }=5\end{array}$ & $\begin{array}{l}\text { upward occupational mobility } \\
=2\end{array}$ & 18 \\
\hline Entrepreneur & - & - & - & \\
\hline White Collar Worker (Clerk)(8) & $\begin{array}{l}\text { downward occupational mobility = } \\
1\end{array}$ & - & non-occupational mobility $=7$ & 8 \\
\hline Total & 12 & 5 & 9 & 26 \\
\hline
\end{tabular}

remark: Upward occupational mobility is define as the cross-occupational mobility from level-1 skill to level-2 skill Downward occupational mobility is define as the cross-occupational mobility from level-2 skill to level-1 skill, and non-occupational mobility is define as the cross-occupational mobility with same skill level.

Table 2: To Show the Methods of Human Capital Accumulation and Occupational Mobility of Female Migrants at Chonburi Province

\begin{tabular}{|c|c|c|c|c|}
\hline \multirow[b]{2}{*}{ Occupational Mobility(number) } & \multicolumn{4}{|c|}{ The methods of human capital accumulation } \\
\hline & Learning from the Job & $\begin{array}{l}\text { Learning from the } \\
\text { Adult Education }\end{array}$ & $\begin{array}{l}\text { Learning in an } \\
\text { Education Institute }\end{array}$ & $\begin{array}{l}\text { Short Course Train- } \\
\text { ing for Occupation } \\
\text { Skills }\end{array}$ \\
\hline \multicolumn{5}{|l|}{ upward occupational mobility (7) } \\
\hline $\begin{array}{l}\text { From blue collar worker to be entre- } \\
\text { preneur }\end{array}$ & $\begin{array}{l}\text { on the job training, } \\
\text { Self learning, information } \\
\text { learning }\end{array}$ & - & - & dress making \\
\hline - $\quad$ From blue collar worker to be clerk & $\begin{array}{l}\text { on the job training, Self } \\
\text { learning, } \\
\text { information learning }\end{array}$ & $\begin{array}{l}\text { attending the non- } \\
\text { formal education for } \\
\text { adults ; evening clas- } \\
\text { ses, classes during } \\
\text { holidays }\end{array}$ & $\begin{array}{l}\text { entering an open } \\
\text { university }\end{array}$ & $\begin{array}{l}\text { basics of computer for } \\
\text { general use }\end{array}$ \\
\hline \multicolumn{5}{|l|}{ downward occupational mobility (2) } \\
\hline $\begin{array}{l}\text { - hotel greeting staff stepped down in } \\
\text { level to be waitress at a noodle shop }\end{array}$ & on the job training & - & - & $\begin{array}{l}\text { basics of computer for } \\
\text { general use }\end{array}$ \\
\hline $\begin{array}{l}\text { cashier in a hotel restaurant stepped } \\
\text { down in level to be shop shelves }\end{array}$ & $\begin{array}{l}\text { on the job training, Self } \\
\text { learning, } \\
\text { information learning }\end{array}$ & - & - & - \\
\hline \multicolumn{5}{|l|}{ non occupational mobility (17) } \\
\hline - $\quad$ Still working as blue collar worker & $\begin{array}{l}\text { on the job training, } \\
\text { self learning }\end{array}$ & - & - & $\begin{array}{l}\text { traditional Thai mas- } \\
\text { sage. } \\
\text { hair dressing }\end{array}$ \\
\hline - $\quad$ Still working as white collar worker & $\begin{array}{l}\text { on the job training, } \\
\text { self learning, information } \\
\text { learning }\end{array}$ & - & - & - \\
\hline
\end{tabular}

\section{Conclusion and recommendations}

The methods of human capital accumulation of migrating women from the rural Northeast to the city of Chonburi created chances of occupational mobility for these women. As is known, Chonburi is the province receiving development in terms of industries, tourism, as well as service sectors. The research revealed that female migrants applied the following methods for accumulating human capital: 1) learn from the job, 2) further their education through adult education, 3) study in an academic institutions, and 4) train 
in professional skills to increase their capabilities of work until they were able to change to a higher career. In addition, occupation mobility correlates to the women's human capital accumulation and personal characteristics. These women were able to change their careers across the categories from Level 1 to Level 2, or an upward mobility. However, occupation mobility occurred only from Level 1 to Level 2 . This could possibly be so because of the limitations in terms of education. It should be noted that the majority of the target group were not able to change their occupations because they lacked the important qualifications. Therefore, relevant governmental organizations should expedite potentiality development for female migrants at the destination in parallel with economic development without any requisite conditions. For instance, female migrants can be trained in occupation skills such as the use of internet in order to obtain information and knowledge useful for their occupation; or they may be supported in terms of opportunities and funds so that female migrants from rural areas are able to establish their own shops or service businesses at the destination as an entrepreneur.

\section{Acknowledgements}

This study is a part of the dissertation entitled, "Capital Accumulation of Female Migrants and Occupational Mobility", the PhD Program in Sociology, Department of Sociology and Anthropology, Faculty of Humanities and Social Sciences, Khon Kaen University, Khon Kaen, Thailand. The researcher would like to thank the Research Scholarship Year 2012 (Grant for a Graduate Lecturer) from the Graduate School, Khon Kaen University for the academic scholarship, the Labour and International Migration Service Center, Faculty of Humanities and Social Sciences, Khon Kaen University, the Research and Training Center for Enhancing Quality of Life of Work-Age People (REQW) of the Faculty of Nursing, Khon Kaen University, Thailand. The researcher is grateful to the research adviser, Associate Professor Dr. Dusadee Ayuwat for her insightful suggestions and constructive comments to improve this paper. Finally, sincere gratitude is extended to all key informants especially the female migrants from the rural areas in the Northeast who participated and provided useful information for this research.

\section{References}

[1] Central Statistical Office, Thailand Population 1960 (1960), Bangkok: Kana Chang Press.

[2] Limanond P \& Thirasawas P (1989), Migration and Develpoment.Bangkok: College of Population studies, Chulalongkorn University.

[3] National Statistic Office, Migration Survey 2005 (2005), Bangkok: National Statistic Office.Minitry of Information and Communication Technology.

[4] National Statistic Office, Migration Survey 2009 round 4 (2009), Bangkok: National Statistic Office.Minitry of Information and Communication Technology.

[5] National Statistic Office, Migration Survey 2013 round 4 (2013), Bangkok: National Statistic Office.Minitry of Information and Communication Technology.

[6] National Statistic Office, The Labour Foecr Survey 2013 (2013), Bangkok: National Statistic Office.Minitry of Information and Communication Technology.

[7] World Bank, Economic Opportunities for women in East ASIA and The Pacific (2012).

[8] Chantavanich S (1991), Social Stratification: Occupational Prestige in Thai Society. Social Research Institute. Chulalongkorn University.

[9] Harvey D (2006), Nole Castree and Derek Gregory,(eds). David Harvey: A Critical Reader. Oxford: Blackwell Publishing.

[10] Ayuwat D (1997), Determinants of Migrants Occupational Mobility. Nakhon Pathom: Institute for Population and Social Research, Mahidol University.

[11] Becker GS (1964), Human Capital. New York: Columbia University Press.
[12] Peer E, Schuller P \& Willims S (2006), 'Innovation at work: The European Human Capital Index'. The Lisbon Council Policy Brie 1(2), 2-4.

[13] Sorensen AB (1975), 'The structure of intragenerational mobility'. American Sociological Review, 40(August), 456-417.

[14] Dunkerley D (1975), Occupational and Society. London: Routledge \& Kegan Paul.

[15] International Labour Organization, Resolution Concerning Updating the International Standard Classification of Occupations.[on line]2008 [cite 2016 Feb 27].Available from: ttp://www.ilo.org/public/english/bureau/stat/isco08/index.htm (2012).

[16] National Statistic Office, Migration Survey 2005 (2011), Bangkok: National Statistic Office.Minitry of Information and Communication Technology.

[17] Yin RK. Case Study Research Design and Methods. 2 nd . Thousand oaks, California. Sage.

[18] Creswell JW (1994), Qualitative Inquiry and Research Design: Choosing Among Five Traditions.Thousand oaks, CA.Sage. 